\title{
Stability and repair works in a cave built with brick arches and vaults in Chinchón (Madrid)
}

\author{
E. González \& T. Fernández \\ ${ }^{1}$ University of Alcalá de Henares, Spain \\ ${ }^{2}$ Technical University of Madrid, Spain
}

\begin{abstract}
This paper describes the unexpected finding of a cave built with brick arches and vaults located $10 \mathrm{~m}$ under a house in Chinchón (Madrid). One of the main arches had settled down $14 \mathrm{~cm}$, another had collapsed, and a steel beam supporting the main gallery was also found. There is no evidence of any written or graphic document of its existence. One of the most interesting features of the cave is its depth and the adoption of a vaulted system. Additionally, floor and elevation plans appear to be very similar to a small chapel with an irregular polygonal apse covered with a semi-spherical brick vault. Next to this apse a semicircular brick-arched ceiling supported by the two main semicircular arches is developed with a similar appearance to that observed in a transept, which may suggest a religious purpose.

This article describes the proportions, the stability, the 'equilibrium approach' of loads and the resistance of brick arches and vaults, explaining why this cave was reinforced with brickwork while many others were not. This study includes the following: a) properties of materials; b) brickwork geometry; c) calculation of loads and d) application of Masonry Structural Theory developed by Heyman, which is the key to a deeper understanding of masonry structures and repair needs.
\end{abstract}

Keywords: brick arches and vaults, masonry structural studies, line of thrust, underground constructions, construction history, rehabilitation works.

\section{Introduction}

Cave construction in this village was a common practice in the seventeenth and the eighteenth centuries. Analysis of the conditions in these constructions has 
revealed structural decay due to poor conservation, which has led to collapse in many cases. This paper is based on the study where a documental historical approach has been carried out in the Historical Archive of Chinchón. This study revealed that both the house and the cave were built before 1754 and they could even be built as early as 1696 (González [1]). The following paper has shown a research into the main features of caves or underground constructions with brick arches and vaults in this village (González [2]).

In the current paper, information about the construction of the cave shows most important geometric data necessary in a structural study. One of the main arches had descended $14 \mathrm{~cm}$, another had collapsed, and a steel beam supporting the main gallery was also found on site. This paper presents the main outcomes as regards: a) the drawing of arches, semicircular and segmental, b) dimensions: span, depth and width; c) arch bonds: bricks laid on edge or bricks laid flat, and d) joints between arches and pillars or masonry walls.

Finally, a study of proportions to demonstrate its stability and so to understand the balance between forces and thrust will help determine, safety margins and explain why this cave in particular was reinforced with brick while many others were not. The analysis was conducted as follows: a) properties of materials, b) geometry of the construction elements under study, c) loads, and, d) the application of Masonry Structures Theory as developed by Heyman [3] and its 'safe theorem'. If the cave has not collapsed, it could be asserted without any doubt that it will be possible to find an equilibrium situation between loads and thrusts.

\section{Documental historical approach}

Chinchón is well known for its tradition in wine and oil production. Many houses built in the seventeenth and the eighteenth centuries had a cellar and a cave to store and keep wine in sound condition (Fundación COAM [4]). Those caves commonly consisted of galleries with different arch shapes, rarely with cross vaults and on most occasions without vaulting. Also common is the finding of huge earthenware jars placed at both sides of the gallery. Some galleries are circular shaped and crossing galleries are uncommon. People could even build the caves by themselves without reinforcing work, this practice being favoured by the special earth conditions of the region. In particular, the cave presented in this paper, is different from others regarding its depth, its plan, and its reinforcing construction system made of brick arches and vaults. Documents consulted in the Historical Archive of Chinchón revealed that construction details, such as houses and caves plans, were not recorded in official documents at that time.

Spanish Construction Treaties of the seventeenth and eighteenth centuries include general rules to dimension arches, vaults and the abutments employed in resisting thrust. Tosca 1727 [5] states that "The following rules are mostly based on the experience and not on a Mathematic demonstration". Following Tosca, there is no doubt that arches and vaults develop a great thrust against the abutments because they are built with wedge shaped stones. As gravity acts 
downwards, the wedge shape added press each other and all together to the walls that support them. For that reason, these walls, called counterforts, must be proportionally reinforced to counteract the thrust. To give them a dimension is necessary to pay attention to the arch shape and the wall height.

Rieger 1763 [6] states that in spite this lightening, if stones are arch wedge shaped, there is always a thrust acting on both sides, which must be calculated depending on the arch shape and its height. In underground constructions, the thrust is smaller due to the counter part that the ground makes against them; if arches are built above ground level, it must be taken into account first that the higher the pillars the more likely they collapse at the base. With regard to the arch thickness required for an underground construction, as it is the case of this cave built 10m underground, Tosca [5] affirms that there is not a unique solution when dimensioning the thickness of an arch and that a sensible architect must design it based on the material resistance used to build it, and the load the arch must support.

\section{Description of the actual cave}

\subsection{Brick arches and vaults geometry}

The cave in San Antón 10 (Chinchón), located $10 \mathrm{~m}$ underground, features brick arches and vaults and 13 earthenware jars. Plan drawings show that the joint of the two axes the long one measuring about $30 \mathrm{~m}$ and the short one $8.65 \mathrm{~m}$ is located in the centre of the main courtyard of the house. Excavations works have revealed three connected elements between the house and the cave: a trapdoor in the kitchen, the cellar on the ground floor and the garden, but interruption of works at the end of the main axe due to the collapse of the gallery raises new doubts about the real extension of the cave.

The first part of the gallery situated on ground level descending 38 steps, is built without brick work, as it is the common practise in this village. After going straight for $5 \mathrm{~m}$ and changing the direction for another $9.40 \mathrm{~m}$ that is the points where brickworks start. There are two stretches of different sizes built with segmental arches, the first one is $1.68 \mathrm{~m} \mathrm{x} 1.60 \mathrm{~m}$ and the second one is $1.68 \mathrm{~m} \mathrm{x}$ $1.25 \mathrm{~m}$. The four arches perpendicular to the previous ones, are raised lower than the ones described before, two of them are built one foot depth with two separate leaves laying on edge, and the other two ones, with bigger spans, being similar. Four large earthenware jars are placed just behind them. This part of the arch ceiling is semicircular and it is not made of brick. Walls going along the longitudinal axe before the axis crossing have been masonry built. The last part of this main axe shows the same construction pattern, two stretches nearly square in shape with segmental brick arches and four large earthenware jars.

Most interesting brickwork is placed in the secondary axe built under the main courtyard of the house which has a bigger span surpassing the full height of the longitudinal axe. This perpendicular axe is finished as an irregular polygonal apse of a span of $3.45 \mathrm{~m}$ and a height of $4.60 \mathrm{~m}$. Walls are masonry built with big stones and have three brick courses laid flat, each $1.20 \mathrm{~m}$ high, from floor level to 
98 Structural Studies, Repairs and Maintenance of Heritage Architecture XI

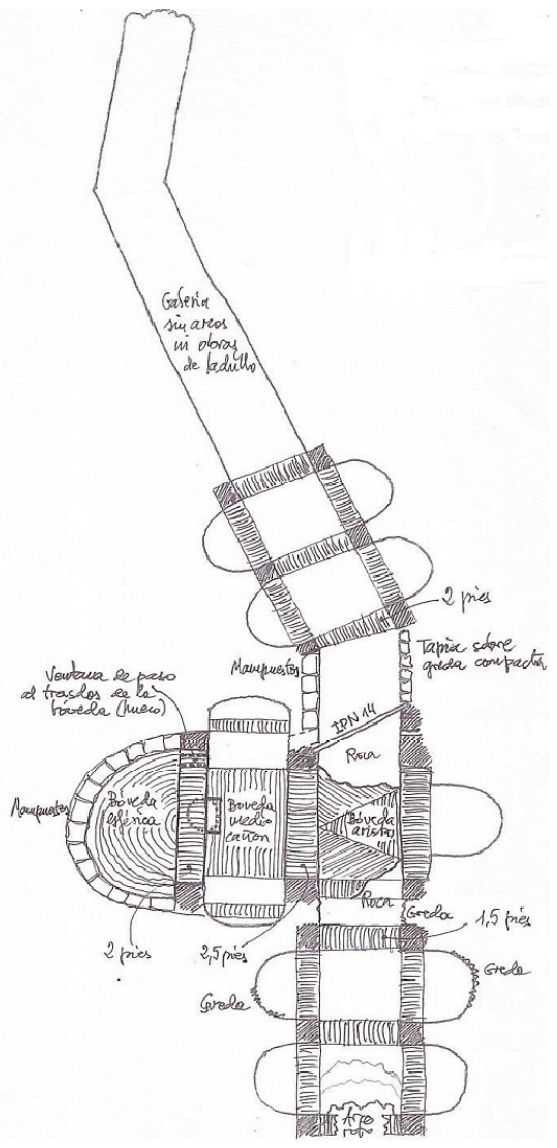

Figure 1: $\quad$ Cave floor plan (Jiménez J., 2005).
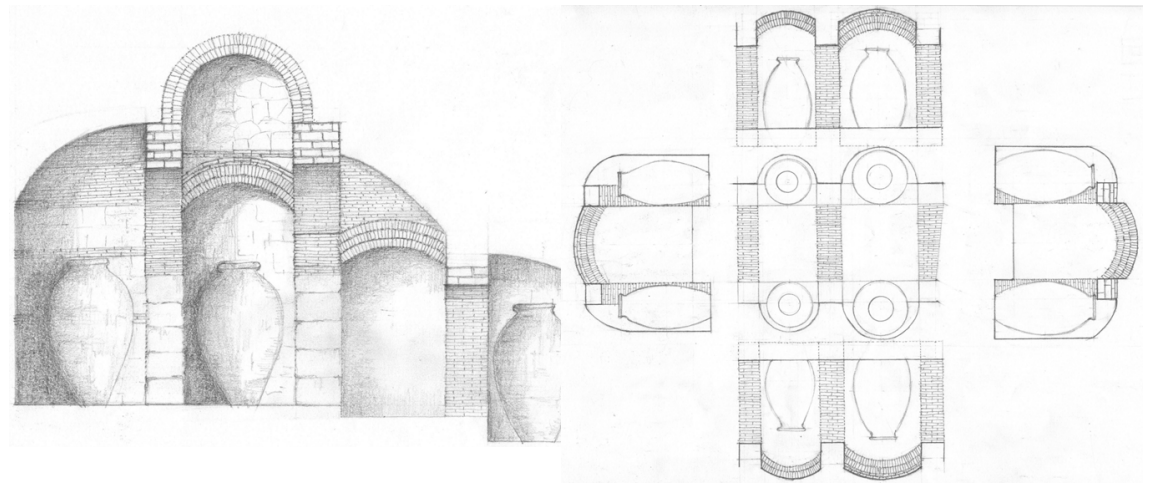

Figure 2: $\quad$ Perpendicular axe cross section and main longitudinal gallery (González [2]). 
the raise of the spherical vault. Two huge earthenware jars, the largest one being $2.25 \mathrm{~m}$ high, are placed in this apse. Next to it a barrel vault, of $1.72 \mathrm{~m}$ in span and a height of $5.50 \mathrm{~m}$ has been built. It is $3.90 \mathrm{~m}$ long and it is caped at both ends with two segmental brick arches. It is supported by the two main semicircular arches. A round brick chimney is opened in the vault showing the place where the cave was found. It is also possible to go to the upper part of this vault thanks to the existing of an opening.

The most original work of the whole construction is the raising of the two main arches. Both of them are built with five separate brick-on-edge courses making them very innovative. The first and biggest one has a span of $3.05 \mathrm{~m}$ and it is $2 \frac{1}{2}$ feet thick. Figure 3 shows the movement produced in this arch, as its central part has descended around $14 \mathrm{~cm}$. The second and smaller one is also semicircular and brick built with a span of $2.10 \mathrm{~m}$. Next to this arch a cloister vault one brick thick has been built with $1.62 \mathrm{~m}$ of span. Its main dimensions are $2.10 \mathrm{~m} \times 1.62 \mathrm{~m}$, it is raised from $2.70 \mathrm{~m}$ in the lowest part going up to $3.75 \mathrm{~m}$ in the highest part. This axe is topped with a segmental arch built with a span of $2.10 \mathrm{~m}$ and a width of $0.65 \mathrm{~m}$. It is $1 \frac{1 / 2}{2}$ brick thick built with two separate leaves of brick laid on edge and over them two more brick courses laid flat.

\subsection{Main features}

The depth of these underground constructions is an important factor to keep wine in good conditions but the cave studied in this paper which has an annual temperature average of $12^{\circ} \mathrm{C}$ is deeper than most of them Maybe the special earth condition in this high part of the village where there are very few caves and previous collapses that have taken place, is the reason why it is located deeper in order to find a resistance ground.

The interior with a height of $5.65 \mathrm{~m}$ can be also considered over dimensioned for its purpose, just to place huge earthenware jars, the biggest ones of $2.20 \mathrm{~m}$ high. Earthenware jars were dragged down the gallery on rugs and once they were at their definite places they were just raised and left there as they can be seen today. Therefore the rules followed in these underground constructions were based on the width and height of the earthenware jars to be placed in.
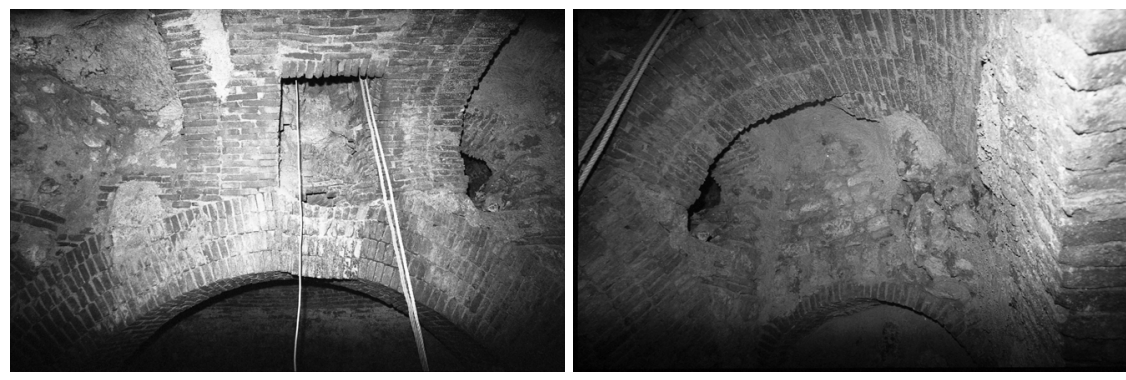

Figure 3: $\quad$ Semicircular vault. 
The construction developed in the crossing of the two galleries at right angles, with such a big height just to place four earthenware jars is also curious. Other caves have lower interior height and as many earthenware jars as could fit in.

As it has been pointed out in previous lines, although in underground constructions the thrust against the walls is smaller, in this case, due to the interior height, it must be taken into account first that the higher the pillars are, the easier they can collapse in the base. Both features, the slenderness of the cave and its depth had led to the brick reinforcement of this cave searching for security.

\subsection{Description of damages}

A number of pathologies after its discovery have been observed and measured and therefore a study including structural analysis of this construction has been considered necessary. Big piles of rubbles in the gallery made works after its discovery difficult to be carried out. The most relevant pathology is the movement of the keystone of the main arch as it has descended vertically $14 \mathrm{~cm}$, although it has not collapsed. As it can be seen in figure 3, over this arch a round brick chimney of about $80 \mathrm{~cm}$ is opened. It has been used for a long time as a fosa séptica. Consequently, the deformation of the main arch might be due to the persistent vertical load that for a long time has been thrown down through this chimney. Although no written report about restoration works carried out before the actual one has so far been found, a corroded steel beam (IPN 14) supporting the main gallery was found. Maybe collapse at the end of the gallery made the cave been reinforced; however, cracks have not been observed.

\section{Application of the masonry structures theory to main arches}

This paper presents the results of the application of the Masonry Structures Theory and its 'safe theorem' [3] to the crossing area of the cave built with brick arches and vaults.

\subsection{Masonry structures theory: 'the safe theorem'}

The safe theorem states the following: 'any masonry arch is safe when a line of thrust, in equilibrium with external loads and lying fully within the thickness of it can be found and the corresponding stresses are sufficiently low'. When supporting walls are appropriate, masonry structures failure, is mainly related to its shape (its geometry), and not to the material crushing (its resistance). This theory can be applied not only to arches but to any other masonry structure.

The cave which is more than 250 years old has not collapsed in this crossing area meaning that it is possible to find an equilibrium solution between loads and thrusts. One of the main aims of this paper is to find out a thrust line lying all over inside the arch and vaults thickness so the structure safety can be assured rationalizing as well main features of this cave. 


\subsection{Steps taken into the analysis}

The steps taken into the structural analysis of the crossing area of the cave have been the following: a) properties of materials, b) geometry of brick works showing the drawing of arches and vaults, c) calculation of weights supported by arches and vaults considering the fact of underground construction, and d) application of Masonry Structural Theory. Line of thrust shape in underground constructions may vary considerably based on different backfill hypothesis: a) backfill hypothesis as a vertical load over the vault and vertical cuts in the voussoirs considering the total thickness of the arch as if it had been made of stone, b) hydrostatic hypothesis or normal pressure over the vault proportional to the height in each part, and c) Rankine's hypothesis, situation in between the two ones described before, (line of thrust variation for angles $25^{\circ}, 35^{\circ}, 45^{\circ}$ ). Following Huerta [7] different studies have been carried out, such as, Harvey (1987), Scheffler (1857) and Gaudí in the Güell Park. In the present paper we have just considered the first situation, the backfill hypothesis as a vertical load over masonry structures, which is the most common procedure for being on the safe side.

Table 1: $\quad$ Loads taken into the analysis.

\begin{tabular}{|c|c|c|c|c|c|c|c|}
\hline \multicolumn{8}{|c|}{ BARRELL VAULT (y axis) } \\
\hline \multirow{6}{*}{ 岂 } & & $\mathrm{h}(\mathrm{m})$ & $\mathrm{L}(\mathrm{m})$ & $\mathrm{L}^{\prime}(\mathrm{m})$ & $\mathrm{V}\left(\mathrm{m}^{3}\right)$ & $\gamma\left(\mathrm{t} / \mathrm{m}^{3}\right)$ & $P(t)$ \\
\hline & $1^{\prime}$ & 4.10 & 0.20 & 0.53 & 0.430 & 2.0 & 0.869 \\
\hline & $2^{\prime}$ & 4.20 & 0.20 & 0.53 & 0.441 & 2.0 & 0.882 \\
\hline & $3^{\prime}$ & 4.30 & 0.20 & 0.53 & 0.451 & 2.0 & 0.903 \\
\hline & $4^{\prime}$ & 4.50 & 0.20 & 0.53 & 0.472 & 2.0 & 0.945 \\
\hline & $5^{\prime}$ & 4.60 & 0.20 & 0.53 & 0.483 & 2.0 & 0.966 \\
\hline \multirow{5}{*}{$\frac{5}{5}$} & $1^{\prime}$ & 0.30 & 0.20 & 0.53 & 0.032 & 2.0 & 0.051 \\
\hline & $2^{\prime}$ & 0.30 & 0.20 & 0.53 & 0.032 & 1.60 & 0.051 \\
\hline & $3^{\prime}$ & 0.30 & 0.20 & 0.53 & 0.032 & 1.60 & 0.051 \\
\hline & $4^{\prime}$ & 0.40 & 0.20 & 0.53 & 0.042 & 1.60 & 0.067 \\
\hline & $5^{\prime}$ & 0.80 & 0.20 & 0.53 & 0.084 & 1.60 & 0.135 \\
\hline
\end{tabular}

Once the different construction elements have been measured, we proceeded to calculate the loads. The steps taken into the analysis have been the following: a) floor and elevation plans showing the hypothesis made, b) vertical cut plans in backfill and arches considered as its total thickness, and c) loads estimation: backfill as a vertical surcharge $(2.0 \mathrm{~kg} / \mathrm{m} 3)$ and brick masonry with lime mortar charge $(1.60 \mathrm{~kg} / \mathrm{m} 3)$; the total load is the result of the weight of the arch plus the load of the backfill which is different from the backfill height in each cut made.

\subsection{Analysis of the stability of the cave: an approach to equilibrium}

The secondary axe of the cave where main features have been shown has been studied as follows: a) main plans such as floor plans, elevation plans and cross 
section of the crossing area have been drawn, b) vertical cuts have also been drawn showing half of the structure to be analysed, and c) once the loads have been calculated a horizontal thrust in the keystone has been considered to draw a possible line of thrust lying fully within the thickness of it. Equilibrium of this part in order to study which part of the construction thrust, and which one resists that thrust, can be model in two ways: a) consideration of the mechanical behaviour of the apse as if it was made of independent or isolated arches and b) hypothesis of incomplete domes.

\subsubsection{Behaviour of the apse as made of isolated arches}

According to Heyman [3], the apse can be considered as a semispherical dome divided into parallel arches being all of them of different sizes where stability is studied for each one. The analysis the behaviour of the apse behaviour was made of independent arches, being each one in equilibrium when they are considered separately. The lateral thrust due to the semicircular vault on the main arch has been considered. This arch is maintained vertically in one side through a balanced force in this arch, its weight, which centres the line of thrust and, in the other side, the other arch considered of uniform thickness $(70 \mathrm{~cm})$, and the cloister vault in the other part equilibrate this thrust. Once the thrust against the main arch is known, the stability of the main arch in the cross section can be noted. Graphical analysis has shown the application of equilibrium to illustrate that the cave 'is standing up'.
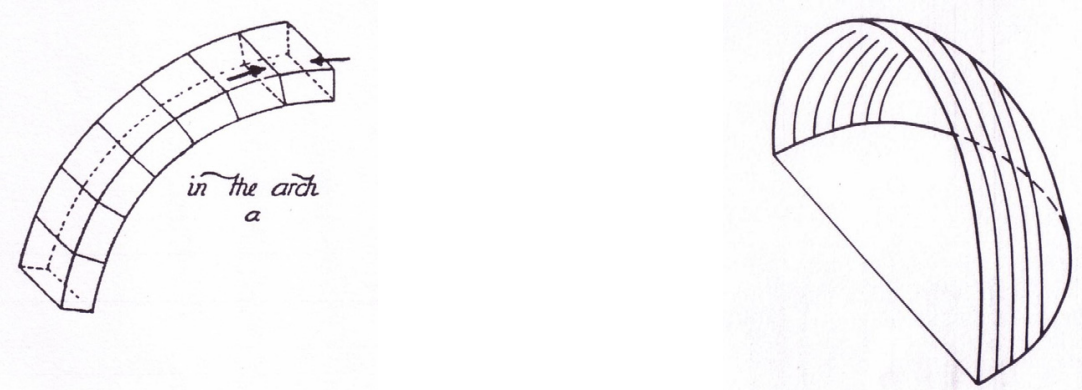

Figure 4: $\quad$ Isolated arches hypothesis (Huerta [7] and Heyman [3]).

\subsubsection{Incomplete hemisphere hypothesis}

Due to symmetry conditions of the construction, a second approach seems to be nearer the actual behaviour of this masonry construction. It has been considered that the apse is an incomplete dome made in such a way that could be understood as divided in segments (Heyman [3]). The value of this thrust is calculated dividing the total area into five parts or segments and then calculating the loads of the elements $\left(P_{i}=A_{i} 2 \pi r i\right)$. It can be assumed that this dome acts as a vault with a horizontal thrust against the barrel vault along the $y$ axe. Decomposing the thrust in each segment in two components along $x$ and $y$ axes the result is that the total horizontal thrust of the apse along the $y$ axe (the thrust against the $x$ axe is balanced in pairs at both sides) is balanced by the total horizontal thrust of the 
barrel vault considered as $q l / 2$ in one side. The cloister vault in the other side also considered as a certain semi dome will equilibrate this thrust.

Next, the line of thrust along the $x$ axe of the crossing area, which is shown in main arches elevation plans, represents how this arch transmits its weight towards the lateral walls and centres the thrust line. The stability of main arches can be assessed and the safety factor calculated. Graphical analysis in figure 6 shows steps and results from this second analysis. The results obtained graphically show that the lateral thrust of the barrel vault is balanced by the arch and the lateral walls, which are great enough to prevent from overturning and subsequent sliding. This approach to equilibrium illustrates that the cave 'is standing up', leaving aside the interest to obtain the actual state of internal stresses in this cave. Graphical analysis developed showed that the stability of main arch is widely assessed along the $x$ axis but, as it was stated in previous lines due to the slenderness of this section, along the $y$ axis security margins are not as high.
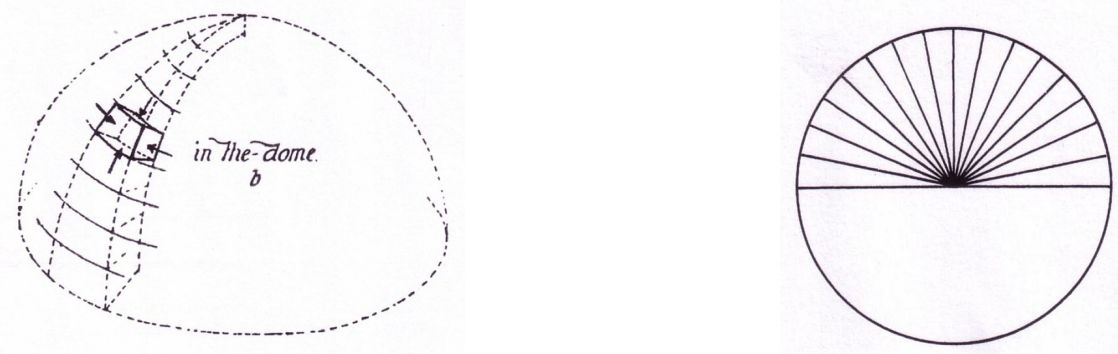

Figure 5: $\quad$ Incomplete domes hypothesis (Huerta [7] and Heyman [3]).

Table 2: $\quad$ Loads taken into the polygonal apse analysis.

\begin{tabular}{|c|c|c|c|c|c|c|c|}
\hline & & $\begin{array}{r}\mathbf{P O} \\
\text { (Incor }\end{array}$ & $\begin{array}{l}\text { YGON } \\
\text { plete he }\end{array}$ & $\begin{array}{l}\mathbf{A L} \mathbf{A} \\
\mathrm{misph}\end{array}$ & $\begin{array}{l}\text { SE ( } y \text { a } \\
\text { re hypo }\end{array}$ & $\begin{array}{l}\text { xis) } \\
\text { thesis) }\end{array}$ & \\
\hline & & $h(m)$ & $1(\mathrm{~m})$ & $1(\mathrm{~m})$ & $V\left(m^{3}\right)$ & $\gamma\left(\mathrm{t} / \mathrm{m}^{3}\right)$ & $P(t)$ \\
\hline & $6^{\prime}$ & 5.60 & 0.20 & 0.20 & 0.224 & 2.0 & 0.448 \\
\hline & $7^{\prime}$ & 5.60 & 0.20 & 0.40 & 0.448 & 2.0 & 0.896 \\
\hline & $8^{\prime}$ & 5.60 & 0.20 & 0.60 & 0.672 & 2.0 & 1.344 \\
\hline & $9^{\prime}$ & 5.60 & 0.20 & 0.80 & 0.896 & 2.0 & 1.792 \\
\hline$\overline{\underline{x}}$ & $10^{\prime}$ & 5.60 & 0.20 & 1.10 & 1.232 & 2.0 & 2.464 \\
\hline $\bar{v}$ & $11^{\prime}$ & 5.80 & 0.20 & 1.30 & 1.508 & 2.0 & 3.016 \\
\hline & $12^{\prime}$ & 6.05 & 0.20 & 1.40 & 1.694 & 2.0 & 3.388 \\
\hline & $3^{\prime}$ & 6.15 & 0.20 & 1.70 & 2.091 & 2.0 & 4.182 \\
\hline & $14^{\prime}$ & 6.20 & 0.20 & 1.90 & 2.356 & 2.0 & 4.712 \\
\hline & $15^{\prime}$ & 6.50 & 0.20 & 2.10 & 2.730 & 2.0 & 5.460 \\
\hline & $16^{\prime}$ & 6.80 & 0.20 & 2.30 & 3.128 & 2.0 & 6.256 \\
\hline
\end{tabular}

\begin{tabular}{|c|c|c|c|c|c|c|l|}
\hline \multicolumn{7}{|c|}{ POLYGONAL APSE $(y$ axis $)$} \\
\hline \multirow{5}{*}{} & & $\mathrm{h}(\mathrm{m})$ & $1(\mathrm{~m})$ & $1(\mathrm{~m})$ & $\mathrm{V}\left(\mathrm{m}^{3}\right)$ & $\gamma\left(\mathrm{t} / \mathrm{m}^{3}\right)$ & $\mathrm{P}(\mathrm{t})$ \\
\hline $6^{\prime}$ & 0.28 & 0.20 & 0.20 & 0.011 & 1.60 & 0.0179 \\
\hline $7^{\prime}$ & 0.28 & 0.20 & 0.40 & 0.0224 & 1.60 & 0.0358 \\
\hline $8^{\prime}$ & 0.28 & 0.20 & 0.60 & 0.0336 & 1.60 & 0.0537 \\
\cline { 2 - 8 } & 0.28 & 0.20 & 0.80 & 0.0448 & 1.60 & 0.0717 \\
\hline $9^{\prime}$ & $10^{\prime}$ & 0.28 & 0.20 & 1.10 & 0.0616 & 1.60 & 0.099 \\
\hline $11^{\prime}$ & 0.28 & 0.20 & 1.30 & 0.073 & 1.60 & 0.1165 \\
\cline { 2 - 7 } & 0.28 & 0.20 & 1.40 & 0.078 & 1.60 & 0.125 \\
\hline $3^{\prime}$ & 0.28 & 0.20 & 1.70 & 0.095 & 1.60 & 0.152 \\
\hline $14^{\prime}$ & 0.28 & 0.20 & 1.90 & 0.106 & 1.60 & 0.170 \\
\hline $15^{\prime}$ & 0.28 & 0.20 & 2.10 & 0.1176 & 1.60 & 0.188 \\
\hline $16^{\prime}$ & 0.28 & 0.20 & 2.30 & 0.129 & 1.60 & 0.206 \\
\hline
\end{tabular}


Arches and vaults when they support an important weight on the keystone, they use to crack in the intrados at that zone. The same arch opens in the extrados, usually at a distance of one third, moving towards outside The arch studied in this paper is made of brick with five separated leaves laying on edge, and lime mortar. Deformation is different from stone structures where usually cracks appear. The deformation usually consists of small compressions and dilatations of the material so the arch instead of cracking bends and the five separated leaves of brick slide over each other and they descend vertically altogether as it can be seen in figure 3 .

\section{Conclusions}

This cave is an outstanding example of the rich cultural heritage of the seventeenth and the eighteenth centuries in this villa. This study has shown its originality with its great depth, its plans consisting of two galleries crossing perpendicularly, the interior height and the vaulted solution employed to reinforce it. The cave which is more than 250 years old has not collapsed in the crossing area meaning that it is possible to find a balanced solution between loads and thrusts. In this paper a structural analysis of this crossing area applying Masonry Structural Theory has been carried out. A thrust line lying fully inside the arch and vaults thickness has been found and so the structure safety has been

Table 3: $\quad$ Loads taken into the semicircular arch analysis.

\begin{tabular}{|c|c|c|c|c|c|c|c|}
\hline \multicolumn{8}{|c|}{ SEMICIRCULAR ARCH 1 ( $\mathrm{x}$ axis) } \\
\hline \multirow{6}{*}{ 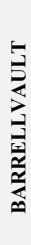 } & & $\mathrm{h}(\mathrm{m})$ & $\mathrm{L}(\mathrm{m})$ & $\mathrm{L}(\mathrm{m})$ & $\mathrm{V}\left(\mathrm{m}^{3}\right)$ & $\gamma\left(\mathrm{t} / \mathrm{m}^{3}\right)$ & $P(t)$ \\
\hline & $1^{\prime}$ & 0.30 & 0.20 & 0.53 & 0.0315 & 1.60 & 0.0504 \\
\hline & $2^{\prime}$ & 0.30 & 0.20 & 0.53 & 0.0315 & 1.60 & 0.0504 \\
\hline & $3^{\prime}$ & 0.30 & 0.20 & 0.53 & 0.0315 & 1.60 & 0.0504 \\
\hline & $4^{\prime}$ & 0.40 & 0.20 & 0.53 & 0.042 & 1.60 & 0.0672 \\
\hline & $5^{\prime}$ & 0.80 & 0.20 & 0.53 & 0.084 & 1.60 & 0.1344 \\
\hline \multirow{6}{*}{$\begin{array}{l}\bar{\Xi} \\
\text { च }\end{array}$} & 1 & 0.30 & 0.20 & 0.56 & 0.034 & 1.60 & 0.0544 \\
\hline & 2 & 0.30 & 0.20 & 0.56 & 0.034 & 1.60 & 0.0544 \\
\hline & 3 & 0.30 & 0.20 & 0.56 & 0.034 & 1.60 & 0.0544 \\
\hline & 4 & 0.40 & 0.20 & 0.56 & 0.045 & 1.60 & 0.0720 \\
\hline & 5 & 0.80 & 0.20 & 0.56 & 0.099 & 1.60 & 0.1584 \\
\hline & 6 & 1.00 & 0.50 & 0.56 & 0.280 & 1.60 & 0.4480 \\
\hline \multirow{6}{*}{ 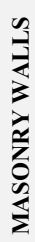 } & 7 & 0.40 & 1.15 & 0.56 & 0.2576 & 1.90 & 0.4890 \\
\hline & 8 & 0.40 & 1.15 & 0.56 & 0.2576 & 1.90 & 0.4890 \\
\hline & 9 & 0.40 & 1.15 & 0.56 & 0.2576 & 1.90 & 0.4890 \\
\hline & 10 & 0.40 & 1.15 & 0.56 & 0.2576 & 1.90 & 0.4890 \\
\hline & 11 & 0.40 & 1.15 & 0.56 & 0.2576 & 1.90 & 0.4890 \\
\hline & 12 & 0.40 & 1.15 & 0.56 & 0.2576 & 1.90 & 0.4890 \\
\hline
\end{tabular}




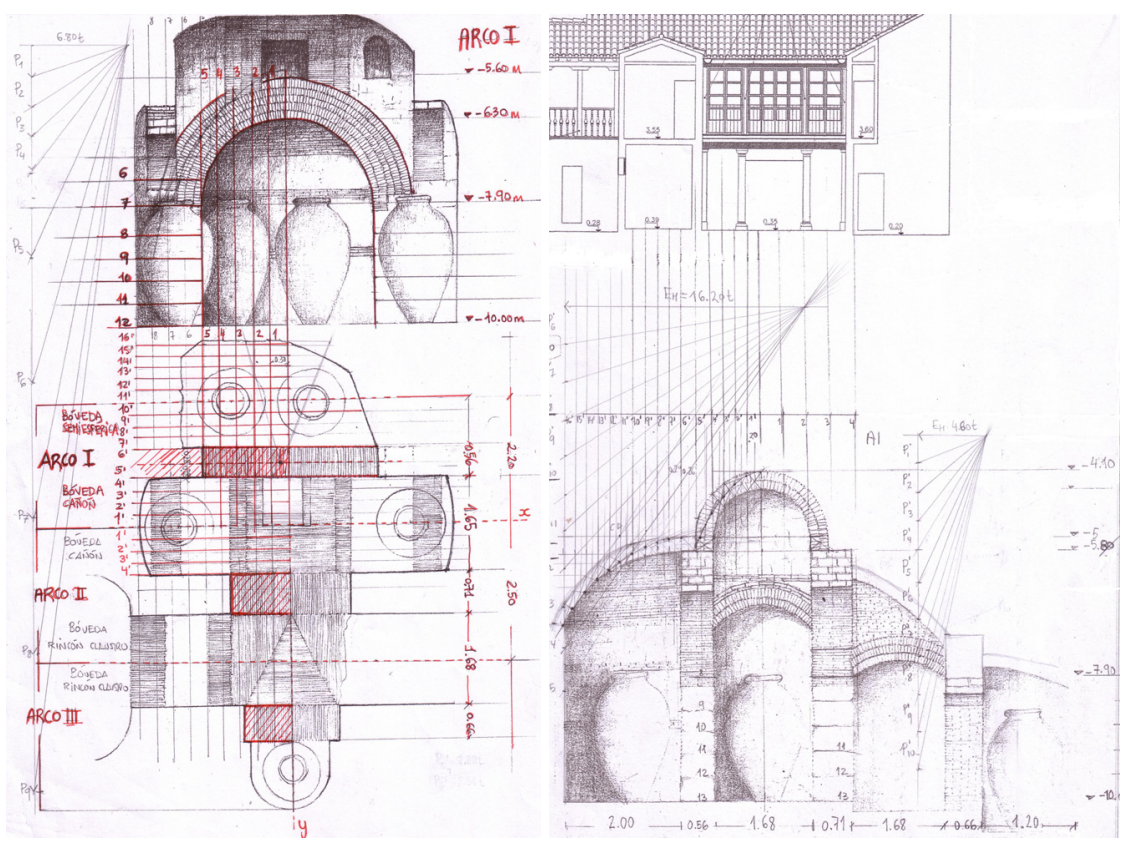

(a)

(b)

Figure 6: Line of thrust: a) main arch and b) cross section.

assessed. Structural approach carried out in this paper will be the starting point of other future studies in order to enrich and thus get a deeper understanding of the structural behaviour of these underground constructions.

\section{Acknowledgements}

Thanks to Julio Jiménez for his helpful photographs, plans and investigation work on an earlier draft of this paper and to Gema López for her great help finding a way to model the structural behaviour of this cave.

\section{References}

[1] González Redondo, E., Construcción de una casa y cueva: recorrido histórico. V Premio de investigación sobre Chichón y su entorno. First Prize. Ayuntamiento de Chinchón, 2008 (forthcoming).

[2] González Redondo, E. Cave Construction with Masonry Arches and Vaults. Proceedings of the Third International Congress on Construction History. Cottbus, 2009. (Forthcoming).

[3] Heyman, J. El esqueleto de piedra. Mecánica de la arquitectura de fábrica. Ed. Instituto Juan de Herrera, CEHOPU, CEDEX, 1999. 
106 Structural Studies, Repairs and Maintenance of Heritage Architecture XI

[4] Fundación COAM, Arquitectura y desarrollo urbano. Tomo XI, Comunidad de Madrid, Chinchón. Ed. Comunidad de Madrid, 2004.

[5] Tosca, T.V. Tratado de la Montea y Cortes de Cantería. Madrid: Imprenta de Antonio Marín, 1727.

[6] Rieger, Ch. Elementos de Arquitectura civil. 1763. Madrid: Instituto Juan de Herrera, 2005.

[7] Huerta Fernández, S., Mecánica de las estructuras de fábrica: arcos, bóvedas y cúpulas. Ed. Instituto Juan de Herrera, 2004.

[8] Essays in the history of the theory of structures. In honour of Jacques Heyman. Ed. Santiago Huerta Fernández, S. 2005. 